\title{
Germination of bur buttercup seeds
}

\author{
JAMES A. YOUNG, ELLEN MARTENS, AND NEIL E. WEST
}

Authors are range scientist and biochemical research technician, USDA, Agricultural Research Service, 920 Valley Road, Reno. Nevada 89512; and professor, range ecology, Utah State University, Logan, Utah 84322.

\section{Abstract}

Bur buttercup (Ranunculus testiculatus Crantz) is an alien annual species that has spread rapidly through range and croplands in the western United States. This species is potentially poisonous and is currently a weed in cereal grain fields. We investigated the germination of the achenes (seeds). About $30 \%$ of the seeds of bur buttercup germinated without pretreatment, but only at cool to cold temperatures (maximum germination $28 \%$ at $5^{\circ} \mathrm{C}$ ). Germination was not enhanced by light, washing, or prechilling of seeds. Acid scarification for 25 minutes increased germination. Enrichment of the germination substrate with $0.289 \mathrm{mmol} \mathrm{L}^{-1}$ gibberellic acid $\left(\mathrm{GA}_{3}\right)$ and $0.01 \mathrm{~mol} \mathrm{~L}^{-1}$ potassium nitrate $\left(\mathrm{KNO}_{3}\right)$ synergistically enhanced the germination of acid scarified seeds. Incubation of seeds pretreated in this manner at 55 constant or alternating temperatures resulted in maximum germination of 70\%. All temperature regimes with optimum germination (defined as not lower than the maximum observed and one-half its confidence interval at 0.01 level of probability) occurred at relatively cool temperatures. Temperatures above $30^{\circ} \mathrm{C}$ greatly suppressed or inhibited germination. Embryonic plants dissected from the achene coats had $60 \%$ germination without additional pretreatment, but only at cool to cold incubation temperatures. The germination-dormancy requirements of bur buttercup seeds are obviously complex, but about $30 \%$ of the seeds appear adapted for germination at cold seedbed temperatures, which fits with the extreme ephemeral growth habit of the species.

Key Words: poisonous plant, range weed, scarification, seed dormancy

Bur buttercup (Ranunculus testiculatus Crantz) was first collected in the United States near Salt Lake City, Utah, in 1932 (Buchanan et al. 1978). It is a diminutive annual about $5 \mathrm{~cm}$ in height, that completes its life cycle in the early spring. Despite the small size of this species, it can carpet thousands of hectares of farm and rangeland in the eastern Great Basin during the period from March to May. This species can be a problem in winter wheat (Triticum aestivum L.) fields (Evans and Gunnell 1986). Bur buttercup contains the toxic substance, ranunculin (Nachman and Olsen 1983). As little as $0.5 \mathrm{~kg}$ of bur buttercup herbage can kills a sheep (Ovis aries) weighing as much as $45 \mathrm{~kg}$ (Olsen et al. 1983). Apparently the species is native to southeastern Europe and southwestern Asia (Benson 1948), but it may exist in these areas as an adventive weed and have an origin in central Asia. Currently, bur buttercup is distributed widely in the temperate desert environment of the Intermountain Area, extending from Utah across northern Nevada to northeastern California (Munz 1973). Small isolated populations are known from northeastern Wyoming, northern Arizona, interior British Columbia, Nebraska, South Dakota, and Kansas (Tuma and Weedon 1989). The first reported herbarium specimen of bur buttercup in Oregon was 1938; Washing-

Manuscript accepted 10 September 1991 ton, 1940; Nebraska, 1970; and Kansas, 1975.

Many annual species native to southwestern and central Asia have successfully invaded the native plant communities of the temperate deserts of western North America (Mack 1981, Young et al. 1972). The interesting aspect of the establishment of bur buttercup is that the spread of this species took place after many other highly competitive, alien annual species were already in place. The annual communities are often considered closed to seedling establishment by other species (Mack 1981).

As an annual species, bur buttercup must produce seeds that germinate rapidly at a time that places the resulting seedlings in a favorable competitive environment and/or dormant seeds must remain in the seedbank to renew the population at opportune times. Obviously, the comparative germination ecology of this species is a key to understanding this colonizing species. Our purpose was to investigate the nature of the dormancy of bur buttercup seeds to determine its influence on germination ecology.

\section{Materials and Methods}

Seeds (achenes) of bur buttercup were collected near Logan, Utah, in 1986 and Alturas, Calif, in 1987 and 1988 . Seeds collected the first year were exhausted by the time preliminary tests were completed. Seeds from the second year collection were used to repeat preliminary tests and to develop second level treatments. Seeds from the third year collection were used to check second level treatments and to develop germination profiles. Seeds were threshed from the bur, cleaned with an air screen and stored at room temperature in the laboratory until tested. Unless otherwise stated, the experimental design consisted of 4 replications of 25 seeds and each was arranged in a randomized block design.

The experimental approach to determining the germination requirement of bur buttercup seeds with unknown types of dormancy involved modifications of the basic algorithm for seed germination developed by the Wildland Seed Laboratory (Young et al. 1984) and Kew Gardens (Ellis et al. 1985).

\section{Preliminary Test}

The steps in this algorithm for bur buttercup seeds were:

1. Control (comparison for all treatments). Incubation of seeds on moist blotter paper in closed petri dishes at $2,5,10$, $15,20,25$, and $30^{\circ} \mathrm{C}$ in a dark incubator for 28 days. Germination counts were made at the end of 7,14 , and 28 days. Seeds were considered germinated when the radicle emerged $5 \mathrm{~mm}$. These same procedures were used in subsequent treatments unless otherwise stated.

2. Afterripening. Repeated incubations at 2, 4, 6, and 12 months after harvest.

3. Prechilling. Seeds placed on moist blotter paper in petri dishes for 2,4 , and 6 weeks at $2^{\circ} \mathrm{C}$ and then incubated for 28 days.

4. Light. Seeds were incubated as in the control, but with illuminance of $175 \mu \mathrm{E} \bullet \mathrm{m}^{-2} \mathrm{~s}^{-1}$ provided by a cool white fluorescent source for 8 hours in each 24 hours. 
Table 1. Germination parameters calculated from quadratic response surfaces (Young et al. 1984).

\begin{tabular}{|c|c|c|}
\hline Calculated parameter & Derivation & Purpose \\
\hline \multirow[t]{2}{*}{ Mean germination } & Igermination & Comparison of profiles \\
\hline & 55 temperatures regimes & \\
\hline \multirow[t]{2}{*}{ Percentage regimes with some germination } & Number of regimes with germination & Indicates breadth of germination response \\
\hline & 55 temperature regime & \\
\hline Optimum germination & $\begin{array}{l}\text { Germination not lower than maximum } \\
\text { observed minus one half confidence interval at } \\
0.01 \text { level of probability. }\end{array}$ & Defined optimum \\
\hline \multirow[t]{2}{*}{ Percentage regimes with optimum germination } & $\begin{array}{l}\text { Temperature regimes with } \\
\text { optimum germination }\end{array}$ & $\begin{array}{l}\text { Indicates breadth of optimum germination } \\
\text { response }\end{array}$ \\
\hline & 55 & \\
\hline \multirow[t]{2}{*}{ Mean of optima } & $\begin{array}{l}\Sigma \text { of germination of regimes with optimum } \\
\text { germination }\end{array}$ & Indicates potential germination \\
\hline & 55 & \\
\hline Maximum germination & Highest observed germination & Potential viability \\
\hline \multirow[t]{2}{*}{ Frequency of optima } & $\begin{array}{l}\text { Number of times temperature } \\
\text { regimes supports optima. }\end{array}$ & $\begin{array}{l}\text { Provides an estimate of optimum temperatures } \\
\text { for germination }\end{array}$ \\
\hline & Total number of tests. & \\
\hline
\end{tabular}

5. Scarification. Seeds were placed in concentrated $(17.28 \mathrm{~mol}$ $\left.\mathrm{L}^{-1}\right)$ sulfuric acid $\left(\mathrm{H}_{2} \mathrm{SO}_{4}\right)$ for $5,10,25$, or 30 minutes and then neutralized with a saturated solution of sodium bicarbonate. Small amounts of seeds were placed in the acid in vials suspended in an ice water bath to reduce damage from heating and were rinsed with a large volume of water before neutralization. The scarified seeds were incubated for 28 days.

6. Hot water. Seeds were dropped into boiling water and immediately removed from the heat and allowed to steep in the cooling liquid overnight. Seeds were incubated for 28 days.

7. Temperature shift. Seeds were incubated at temperature regimes of $5 / 30\left(5^{\circ} \mathrm{C}\right.$ for 16 hours and $30^{\circ} \mathrm{C}$ for 8 hours in each 24 hours), 5/40, 10/30, and $10 / 40^{\circ} \mathrm{C}$.

8. Dry heat. Seeds were incubated at $80^{\circ} \mathrm{C}$ for 56 hours in a forced draft oven. The seeds were then incubated as above.

9. Potassium nitrate enrichment. Seeds were incubated at $15^{\circ}$ $\mathrm{C}$ in petri dishes with the blotter moistened with a $0.01 \mathrm{~mol}$ $\mathrm{L}^{-1}$ aqueous solution of potassium nitrate $\left(\mathrm{KNO}_{3}\right)$.

10. Gibberellin enrichment. Same as step 9 except $0.289 \mathrm{mmol}$ $\mathrm{L}^{-1}$ of gibberellic acid $\left(\mathrm{GA}_{3}\right)$ was substituted for the $\mathrm{KNO}_{3}$.

11. Leaching. Seeds were washed in continuously running tap water for 24 and 48 hours and then incubated.

\section{Second Level Test}

Based on the results from the first 10 steps in the algorithm, second level treatments involved combinations of treatments and expansion of ranges of concentrations or intensities of treatments. Following secondary treatments, seeds were incubated at $15^{\circ} \mathrm{C}$, Secondary, treatments included acid scarification for 25 minutes followed by:

1. Incubation with enrichment of the germination substrate with $0.289,0.578,1.165,1.734$, or $2.312 \mathrm{mmol} \mathrm{L}^{-1} \mathrm{GA}_{3}$.

2. Incubation with enrichment of the germination substrate with $0.01 \mathrm{~mol} \mathrm{~L}^{-1} \mathrm{KNO}_{3}$.

3. Incubation with enrichment of the germination substrate with $0.01 \mathrm{~mol} \mathrm{~L}^{-1} \mathrm{KNO}_{3}$ plus $0.289 \mathrm{mmol} \mathrm{L}^{-1}$ of $\mathrm{GA}_{3}$.

4. Prechilling at $2^{\circ} \mathrm{C}$ for 2,4 , or 6 weeks.

5. Incubation with 8 hours light in each 24 -hour period using the same light conditions as specified in the primary algorithm.
6. Seeds that had been acid scarified were washed in continuously running tap water for 24 and 48 hours.

\section{Temperature Profile}

The secondary treatments that were most successful in enhancing germination were acid scarification for 25 minutes plus incubation with $0.01 \mathrm{~mol} \mathrm{~L}^{-1} \mathrm{KNO}_{3}$ and $0.289 \mathrm{mmol} \mathrm{L}^{-1} \mathrm{GA}_{3}$ enrichment of the substrate. These were used as a pretreatment for seeds for the germination profiles. Incubation temperatures consisted of a constant $0,2,5^{\circ} \mathrm{C}$ and $5^{\circ} \mathrm{C}$ increments through $40^{\circ} \mathrm{C}$. In addition, alternating regimes of 16 hours at each constant temperature plus 8 hours at each possible higher temperature were included. For example, $35^{\circ} \mathrm{C}$ alternated with $40^{\circ} \mathrm{C}$ only, while $0^{\circ} \mathrm{C}$ alternated with $2,5,10,15,20,25,30,35$, and $40^{\circ} \mathrm{C}$ (Young et al. 1973). This made a total of 55 constant and alternating temperature regimes. To compare the germination response obtained from the temperature profile to seedbed temperatures, the temperature regimes of the profile were divided into 6 categories (Young and Evans 1982):

1. Very cold: $0 / 0,0 / 2,0 / 5$, and $2 / 2^{\circ} \mathrm{C}$.

2. Cold: $0 / 10,0 / 15,2 / 5,2 / 10,2 / 15,5 / 5$, and $5 / 10^{\circ} \mathrm{C}$.

3. Cold fluctuating: $0 / 20$ through $0 / 40^{\circ} \mathrm{C}$ and $2 / 20$ through $2 / 40^{\circ} \mathrm{C}$.

4. Fluctuating: $5 / 30$ through $5 / 40^{\circ} \mathrm{C}, 10 / 35,10 / 40$, and $15 / 40^{\circ} \mathrm{C}$.

5. Moderate: $5 / 15$ through $5 / 25^{\circ} \mathrm{C}, 10 / 10$ through $10 / 30^{\circ} \mathrm{C}$, $15 / 15$ through $15 / 35^{\circ} \mathrm{C}, 20 / 20$ through $20 / 35^{\circ} \mathrm{C}, 25 / 25$ and $25 / 30^{\circ} \mathrm{C}$.

6. Warm: $20 / 40,25 / 35$, and $25 / 40^{\circ} \mathrm{C}, 30 / 30$ though $30 / 40^{\circ}$ C, $35 / 35,35 / 40$, and $40 / 40^{\circ} \mathrm{C}$.

These categories of seedbed temperatures, based on several years of microenvironmental monitoring (Evans et al. 1970; Evans and Young 1970, 1972), reflect spring germination field conditions in the big sagebrush zone of the Great Basin.

Data from each base temperature and its alternating temperature regimes were used to develop regression equations that in turn were used to generate a quadratic response surface with estimated germination means and confidence intervals at the $1 \%$ level of probability (Evans et al. 1982). A number of germination parameters were synthesized from the quadratic response surfaces (Table 1) (Young and Evans 1982). These were used to assist in interpreting the germination-temperature profiles. For comparison with the germination characteristics of bur buttercup, we used the mean values from 6 profiles of downy brome (Bromus tectorum L.) 
previously published by Young and Evans (1982).

\section{Nature of Dormancy}

A series of experiments were conducted to help define the nature of the dormancy of bur buttercup seeds. The indurate achene coats were clipped or cut in separate treatments at the pointed apex, the scar of attachment end, or the side of the achene. The treated achenes were incubated at $5^{\circ} \mathrm{C}$. Embryos were also dissected from the achene coat and incubated at 5,15 , and $25^{\circ} \mathrm{C}$. In an additional experiment, dissected embryos were incubated in the same petri dish with equal numbers of intact achenes, with 5 times the number of intact achenes, or with the remnants of the achene coats from which they were dissected. These plates were incubated at $5^{\circ} \mathrm{C}$.

\section{Statistical Analysis}

Results were subjected to analysis of variance after appropriate transformations were made based on a test of homogeneity of variances. Means were separated using Duncan's Multiple Range Test at the 0.01 level of probability.

\section{Results and Discussion}

\section{Primary Test}

Seeds of bur buttercup germinated only at very cold incubation temperatures with maximum germination of $28 \%$ occurring at $5^{\circ} \mathrm{C}$ (Table 2), suggesting a prechilling requirement that was being

Table 2. Preliminary treatments to enhance the germination of seeds of bur buttercup. Seeds incubated at $5^{\circ} \mathrm{C}$ for 28 days.

\begin{tabular}{lc}
\hline \hline Treatment & Germination \\
\hline Control & $28 \mathrm{bc}$ \\
Afterripening & No change \\
Prechilling for 6 weeks & $13 \mathrm{~d}$ \\
Light & $28 \mathrm{bc}$ \\
Scarification & \\
Hot water (pretreatment) & $36 \mathrm{a}$ \\
Temperature shift (multiple treatments) & $0 \mathrm{e}$ \\
Dry heat (pretreatment) & $0 \mathrm{e}$ \\
$\mathrm{KNO}_{3}$ & $0 \mathrm{e}$ \\
$\mathrm{GA}_{3}$ & $34 \mathrm{ab}$ \\
Wash (pretreatment) & $22 \mathrm{c}$ \\
\hline
\end{tabular}

IMeans followed by the same letter are not significantly different at the 0.01 level of probability as determined by Duncan's Multiple Range test.

${ }^{2}$ Acid scarification for 25 minutes.

partially satisfied during the 28-day incubation period. Prolonged prechilling for 6 weeks did not enhance germination and even reduced subsequent germination (Table 2). The restriction of germination to low temperatures did not spontaneously disappear over time in the nature of an afterripening requirement. One-yearold seeds had the same germination response to incubation as freshly harvested seeds (data not shown). Providing light during incubation had no influence on germination of bur buttercup seeds (Table 2).

The 3 preliminary treatments that involved high incubation or pretreatment temperatures were hot water, temperature shift, and dry heat, which inhibited the subsequent germination of bur buttercup seeds (Table 2). Wide diurnal fluctuations in incubation temperature from cool to hot can be an effective germination environment for seeds of some species (Semenza et al. 1978), but not bur buttercup. Hot water treatment is often viewed as a form of scarification (Young and Young 1985) because the thermal shock may crack hard seed coats. Acid scarification is effective is enhancing germination of bur buttercup seeds, but hot water treatment inhibits germination.

Acid scarification for 25 minutes produced significantly $(P \leq 0.01)$ higher germination than untreated seeds incubated at $5^{\circ} \mathrm{C}$ (Table 2). Acid scarification for 10 through 30 minutes was not signifi- cantly different in enhancing germination (data not shown). The acid scarification for $\mathbf{2 5}$ minutes was most effective in producing germination at higher incubation temperatures where untreated seeds did not germinate.

Enrichment of the germination substrate with $\mathrm{KNO}_{3}$ produced germination overlapping with untreated or acid scarified seeds (Table 2). Enrichment with $\mathrm{GA}_{3}$ did not enhance germination of bur buttercup seeds.

After the preliminary experiments, it was apparent that the dormancy of bur buttercup seeds had some relation to the diffusion of germination enhancing or inhibiting material through the achene coat because of the positive response to scarification. The seeds appeared very sensitive to high incubation temperatures.

\section{Second Level Treatments}

Germination of bur buttercup seeds was $49 \%$ after 25 minutes acid scarification (Table 3). This was more than $10 \%$ higher than

Table 3. Secondary treatments of bur buttercup seeds that were pretreated by acid scarification for 25 minutes. ${ }^{1}$

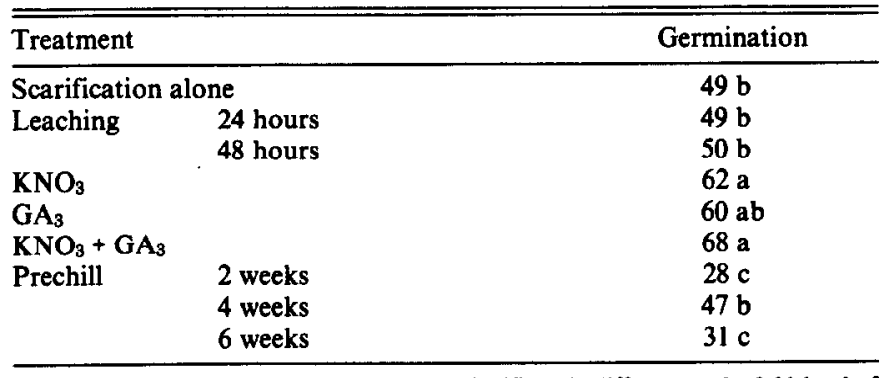

1Means followed by the same letter are not significantly different at the 0.01 level of probability as determined by Duncan's Multiplc Range test.

the mean germination obtained with seed produced on the same site the previous year (Table 2). Repeated tests showed there was a significant year of seed production interaction in the amount of germination obtained following acid scarification, but not in the duration of scarification treatment required to enhance germination (data not shown).

Buchanan et al. (1978) presented experimental evidence that seeds of bur buttercup produced allelopathic influences on the germination of seeds of grass species. We were not any more successful with leaching germination inhibitors from acid scarified seeds of bur buttercup than we were with intact seeds (Table 3).

Prechilling was sometimes detrimental to subsequent germination of acid scarified seeds (Table 3). Prechilling is often detrimental to the germination of scarified seeds, apparently, because of damage from the scarification to the achene or seed coat and pericarp which are natural defenses against micro-organisms. In the case of bur buttercup where the seeds germinate at very low incubation temperatures, it is puzzling that prechilling is detrimental to subsequent germination.

Enriching the germination substrate with $\mathrm{KNO}_{3}, \mathrm{GA}_{3}$, or mixtures of both materials was the most effective secondary treatment for enhancing germination of seeds of bur buttercup (Table 3). Varying the concentration of $\mathrm{GA}_{3}$ did not markedly change the germination response (data not shown).

\section{Germination Profile}

The mean germination for the 55 temperature profile for bur buttercup seeds was only $20 \%$ (Table 4 ). Only $60 \%$ of the temperature regimes supported some germination and the mean germination for regimes where some germination occurred was $30 \%$. Optimum germination occurred at $25 \%$ of the regimes tested and the mean germination of the regimes with optimum germination was $60 \%$. The maximum observed germination was $70 \%$.

Downy brome is the most successful alien annual weed in the 
Table 4. Germination parameters calculated from a germination profile for acid scarified seeds of bur buttercup with the germination substrate enriched with $0.289 \mathrm{mmol} \mathrm{L}^{-1} \mathrm{GA}_{3}$ and $0.01 \mathrm{~mol} \mathrm{~L}^{-1} \mathrm{KNO}_{3}$. Bur buttercup germination parameters are cumpared with those of downy brome (Young et al. 1984).

\begin{tabular}{lcc}
\hline \hline Germination parameter & Bur buttercup & Downy brome \\
\hline Mean germination & $(\%)$ & $(\%)$ \\
Mean germination of regimes with & 20 & 80 \\
some germination & 30 & 80 \\
Regimes with some gerimination & 60 & 100 \\
Regimes with optimum germination & 25 & 20 \\
Mean of optima & 60 & 95 \\
Maximum germination & 70 & 100 \\
\hline
\end{tabular}

temperate deserts of the Intermountain Area. It is the seral dominant of the areas where bur buttercup has been invading. Comparing germination characteristics (Table 4), it is obvious that downy brome is overwhelmingly a more germinable species.

In comparison to seedbed temperatures (Table 5), maximum germination of bur buttercup occurred at cold seedbed temperatures and no germination occurred at warmer than moderate temperatures. Downy brome had greater germination than bur buttercup at all seedbed temperature categories.

Table 5. Germination of seeds of bur buttercup that have been scarified and the germination substrate enriched with $0.289 \mathrm{mmol} \mathrm{L}^{-1} \mathrm{GA}_{3}$ and $0.01 \mathrm{~mol} \mathrm{~L}^{-1} \mathrm{KNO}_{3}$ in relation to categories of seedbed temperatures. Bur buttercup compared to the germination response of downy brome (Young et al. 1984).'

\begin{tabular}{lcc}
\hline \hline Seedbed temperatures & Bur buttercup & Downy brome \\
\hline & $(\%)$ & $(\%)$ \\
Very cold & $18 \mathrm{~b}$ & $37 \mathrm{c}$ \\
Cold & $54 \mathrm{a}$ & $68 \mathrm{~b}$ \\
Cold fluctuating & $15 \mathrm{~b}$ & $89 \mathrm{a}$ \\
Fluctuating & $3 \mathrm{c}$ & $89 \mathrm{a}$ \\
Moderate & $18 \mathrm{~b}$ & $93 \mathrm{a}$ \\
Warmer & $0 \mathrm{c}$ & $70 \mathrm{~b}$ \\
\hline
\end{tabular}

'Means within species followed by the same letter are not significantly different at the 0.01 level of probability as determined by Duncan's Multiple Range test.

Germination of bur buttercup was suppressed greatly or inhibited by warm incubation temperatures. In the germination profile, optimum temperatures for germination occurred at $2 / 2,5 / 5$, and $5 / 10^{\circ} \mathrm{C}$ and temperatures alternating with these cold period temperatures up through $20^{\circ} \mathrm{C}$ (data not shown). In contrast, optimum temperatures for germination of downy brome seeds ranged from 5 to $20^{\circ} \mathrm{C}$ with minimum warm period temperatures of $20^{\circ} \mathrm{C}$ and maximum warm period temperatures of $35^{\circ} \mathrm{C}$ (Young and Evans 1982).

\section{Nature of Dormancy}

Complete dissection of the embryo from the achene coat indicated that 1 portion of the dormancy of bur buttercup seeds was located in the achene coat. Dissected embryos had $65 \%$ germination at $5^{\circ} \mathrm{C}$ (Table 6 ). Clipping portions of the achene coat was not effective in enhancing germination. This indicated that moisture imbibition is not the limiting factor as would be the case with a typical hard seed coat. Acid scarification has been shown to have metabolic influences on germinating seeds outside of mere physical removal of restrictive layers in seed coats (McDonald and Khan 1983).

It is very difficult to dissect embryos of bur buttercup from the achene coat without damaging the embryo. Actual germination of dissected embryos may be higher than the $65 \%$ reported for that
Table 6. Germination of bur buttercup seeds where the achene coat was physically cut or the embryo discussed free of the achene coat.l

\begin{tabular}{lcc}
\hline \hline Treatment & Incubation temperature & Germination \\
\hline & $\left({ }^{\circ} \mathrm{C}\right)$ & $(\%)$ \\
Control & 5 & $28 \mathrm{bc}$ \\
Pointed apex clipped & 5 & $20 \mathrm{~cd}$ \\
Scar end clipped & 5 & $10 \mathrm{~d}$ \\
Side cut & 5 & $40 \mathrm{~b}$ \\
Embryo dissected free & 5 & $65 \mathrm{a}$ \\
& 15 & $40 \mathrm{~b}$ \\
& 25 & $0 \mathrm{~d}$
\end{tabular}

'Means followed by the same letter are not significantly different at the 0.01 level of probability as determined by Duncan's Multiple Range test.

reason. It is important to note that a form of dormancy still exists in the dissected embryos in that germination was highest at $5^{\circ} \mathrm{C}$, dropped to $40 \%$ at $15^{\circ} \mathrm{C}$, and $0 \%$ at $25^{\circ} \mathrm{C}$ (Table 6).

It was not demonstrated in this study that a germination inhibitor could be leached from intact or acid scarified seeds. However when intact achenes were placed in close contact with dissected embryos there was a reduction in germination of the embryos (Table 7). Leaving dissected achene coats in the petri dish with dissected embryos also reduced germination.

Table 7. Germination of bur buttercup embryos dissected from achenes in relation to intact achenes or the dissected achenes in the same petri dish.'

\begin{tabular}{lc}
\hline \hline Treatment & Germination \\
\hline & $(\%)$ \\
Control-dissected embryos & $65 \mathrm{a}$ \\
Five dissected embryos plus 5 intact achenes & $28 \mathrm{~b}$ \\
Five dissected embryos plus 25 intact achenes & $31 \mathrm{~b}$ \\
Five dissected embryos plus the achene coats & $35 \mathrm{~b}$ \\
\hline
\end{tabular}

IMeans followed by the same letter are not significantly different at the 0.01 level of probability as determined by Duncan's Multiple Range test.

\section{Synthesis of Germination Ecology}

A random sample drawn from collections of bur buttercup seeds reveals slight variation in the size of the achenes, but no gross morphological differences among the achenes. There are obvious differences in these collections in the physiological sense. Roughly $30 \%$ of the seeds will germinate, provided low incubation temperatures are provided. Acid scarification will increase the germinable portion an additional $10 \%$ and enrichment with a source of nitrate ions and exogenous application of gibberellin increases germination to a maximum of $70 \%$. There have been several studies of populations of seeds of weed species where dormant and nondormant lines have been identified within the same species and the differences have been shown to be genetically controlled (Probert et al. 1989).

The dormancy of bur buttercup seeds is obviously many faceted with achene coat interference, incubation temperature, nitrate ion source, and gibberellin all influencing ultimate germination. It is much more common for small seeded weed species to have germination requirements that involve light, fluctuating temperatures, and prechilling requirements (Baskin and Baskin 1983).

Everything known about the ecology of bur buttercup points to its being an extreme ephemeral (Buchanan et al. 1978). The capacity for at least a third of the annual seed rain to readily germinate at very cold temperatures is compatible with winter or very early spring germination. Field studies of the periodicity of emergence of bur buttercup seedlings are needed to completely understand the germination ecology of this weed species. 


\section{Literature Cited}

Baskin, J.M., and C.C. Baskin. 1983. Seasonal changes in the germination response of buried seeds of Arabidopsis thaliana, an ecological interpretation. Bot. Gaz. 144:540-543.

Benson, L. 1948. A treatise on the North American Ranunculi. Amer. Midland Nat. 40:1-261.

Buchanan, B.A., K.T. Harper, and N.C. Frischknecht. 1978. Allelopathic effects of bur buttercup tissue on germination and growth of various grasses and forbs in vitro and in soil. Great Basin Natur. 38:90-96.

Ellis, R.H., T.D. Hong, and E.H. Roberts. 1985. Handbook of seed technology for genebanks. II. Compendium of specific germination information and test recommendations. Inter. Board for Plant Genetic Res., Rome.

Evans, J.O., and R.W. Gunnell. 1986. Evaluation of metribuzin and SMY1500 for weed control in winter wheat. Res. Prog. Rep. Western Soc. Weed Sci.

Evans, R.A., D.A. Easi, D.N. Book, and J.A. Young. 1982. Quadratic response surface analysis of seed germination trials. Weed Sci. 30:411-416.

Evans, R.A., H.R. Holbo, R.E. Eekert Jr., and J.A. Young. 1970. Functional environment of downy brome communities in relation to weed control and revegetation. Weed Sci. 18:89-97.

Evans, R.A., and J.A. Young. 1970. Plant litter and establishment of alien annual species in rangeland communities. Weed Sci. 18:697-703.

Evans, R.A., and J.A. Young. 1972. Microsite requirements for establishment of annual rangeland weeds. Weed Sci. 20:350-356.

Mack, R.M. 1981. Invasion of Bromus tectorum L. into western North America: An ecological chronicle. Agro-Ecosystems 7:145-165.

McDonald, M.B., Jr., and A.A. Khan. 1983. Acid scarification and protein synthesis during seed germination. Agron. J. 75:111-114.
Munz, P.A. 1973. Supplement to-A California Flora. Univ. Calif. Press. Nachman, R.J., and J.D Olsen. 1983. Ranunculin: A toxic constitutent of the poisonous range plant bur buttercup (Ceratocephalus testiculatus). J. Agr. Food Chem. 31:1358-1360.

Olsen, J.D., T.E. Anderson, J.C. Murphy, and G.J. Madsen. 1983. Bur buttercup poisoning of sheep. J. Amer. Vet. Med. Assoc. 183:538-543.

Probert, R.J., J.B. Dickie, and M.R. Hart. 1989. Analysis of the effect of cold scarification on germination response to light and alternating temperature using selected seed populations of Ranunculus sceleratus. L.J. Exp. Bot. 40:293-300.

Semenza, R.J., J.A. Young, and R.A. Evans. 1978. Influence of light and temperature on the germination and seedbed ecology of common mullein (Verbascum thapsus). Weed Sci. 26:577-581.

Tuma, W.C., and R.R. Weedon. 1989. Bur buttercup: migrant and killer. Nebraska Section Soc. for Range Manage. Newsletter 38:2-4.

Young, J.A., and R.A. Evans. 1982. Temperature profiles for germination of cool season grasses. ARR-W-22. Agr. Res. Ser., USDA, Oakland, Calif.

Young, J.A., R.A. Evans, and J. Major. 1972. Alien plants in the Great Basin. J. Range Manage. 25:194-201.

Young, J.A., R.A. Evans, and B.L. Kay. 1973. Temperature requirements for seed germination in an annual type range community. Agron. J. 65:656-659

Young, J.A., R.A. Evans, B.L. Kay, R.E. Owen, and J. Budy. 1984. Collecting, processing, and germinating seeds of western wildland plants. ARM-W-3. Sci. Ed. Adm., USDA, Oakland, Calif.

Young, J.A., and C.G. Young. 1985. Germination of seeds of wildland plants. Timber Press, Portland, Ore. 